\title{
Endbulb Synapses in the Anteroventral Cochlear Nucleus Express a Specific Subset of AMPA-Type Glutamate Receptor Subunits
}

\author{
Ya-Xian Wang, ${ }^{1}$ Robert J. Wenthold, ${ }^{1}$ Ole P. Ottersen, ${ }^{2}$ and Ronald S. Petralia ${ }^{1}$ \\ ${ }^{1}$ National Institute on Deafness and Other Communication Disorders/National Institutes of Health, Bethesda, Maryland \\ 20892, and 2University of Oslo, N-0317 Oslo, Norway
}

The anteroventral cochlear nucleus (AVCN) acts as the first relay center in the conduction of auditory information from the ear to the brain, and it probably performs a crucial role in sound localization. Auditory nerve input to the principal neurons of the AVCN, the spherical bushy cells, appears to be mediated by an excitatory amino acid such as glutamate, which acts at a specialized, large synaptic ending called an endbulb of Held. Presumably, endbulb synapses contain some specific combination of glutamate receptors to facilitate rapid neurotransmission of auditory signals. AMPA glutamate receptor composition at the endbulb synapses was examined with both light and electron microscope immunocytochemistry. Electron microscope localization of AMPA receptors was examined with two techniques, preembedding immunoperoxidase and postem- bedding immunogold, which provide maximum sensitivity and greatest accuracy, respectively. Dense and frequent labeling was seen with the AMPA receptor subunit antibodies GluR2/3 and GluR4, which were colocalized at the endbulb synapses. In contrast, immunolabeling with antibody to GluR2 was low. These data indicate that the major glutamate receptor at this synapse is an AMPA receptor made up mainly of GluR3 and GluR4 subunits. Receptors composed of these subunits display properties, such as calcium permeability and rapid desensitization, that facilitate their specialized functions in auditory information processing.

Key words: cochlear nucleus; auditory; AMPA; glutamate receptors; spherical bushy cell; endbulb
The spherical bushy cells of the anteroventral cochlear nucleus (AVCN) receive a direct input from the auditory nerve via a specialized synaptic contact called the endbulb of Held (for review, see Cant, 1992). This endbulb exhibits unique structural and functional specializations used in the initial processing of auditory information in the CNS that are necessary for sound localization and analysis. The endbulb is an enlarged calyx-type terminal that surrounds the bushy cell soma, contains large round vesicles, and forms multiple synaptic contacts with the soma. In addition, the endbulb forms attachment plaques with the soma and forms synapses with dendrites along the endbulb surface, opposite the side of the endbulb that contacts the bushy cell soma. The endbulb provides a secure, excitatory synaptic connection between the auditory nerve fiber and the spherical bushy cell soma; this permits the spherical bushy cell to show a primary-like response almost identical to the response of the auditory nerve (for review, see Rhode and Greenberg, 1992). This allows an auditory spike stream to pass, virtually unchanged, from the auditory nerve to the superior olivary complex (SOC) via the AVCN. Thus, the frequency information of the temporal discharge of the auditory nerve is preserved; this probably is important for the binaural mechanism for sound localization. In addition to the auditory input via the endbulb of Held, the spherical

\footnotetext{
Received Sept. 16, 1997; revised Nov. 6, 1997; accepted Nov. 11, 1997.

This study was supported by the National Institute on Deafness and Other Communication Disorders Intramural Research Program. We thank Dr. M. E. Rubio for many helpful suggestions; Dr. K. K. Osen for preparing some of the tissue used in the preliminary study and for helpful suggestions; A. S. Landsend, B. Riber, and K. M. Gujord for help and advice on the immunogold technique; Dr. J. Fex for reviewing this paper; and Dr. P. Streit for providing monoclonal GluR2/3.

Correspondence should be addressed to Ronald S. Petralia, National Institute on Deafness and Other Communication Disorders/National Institutes of Health, 36/ 5D08, 36 Convent Drive, MSC 4162, Bethesda, MD 20892-4162.

Copyright (C) 1998 Society for Neuroscience $\quad 0270-6474 / 98 / 181148-13 \$ 05.00 / 0$
}

bushy cell receives inputs from other nuclei, including tuberculoventral cells of the deep dorsal cochlear nucleus, a few interneurons of the ventral cochlear nucleus, the contralateral cochlear nucleus, and the SOC (Wenthold and Hunter, 1990; Wickesberg et al., 1994; Juiz et al., 1996a,b; Yao et al., 1996); presumably these other inputs are necessary to obtain the proper response pattern of the spherical bushy cell.

The spherical bushy cell auditory nerve-endbulb synapse is believed to be glutamatergic (for review, see Wenthold et al., 1993; Hackney et al., 1996). Spherical bushy cells contain mRNA for AMPA receptors (Hunter et al., 1993). Also, preliminary studies have indicated the presence of AMPA and other glutamate receptors (NMDA, kainate, delta, metabotropic) (Petralia and Wenthold, 1992; Hunter and Wenthold, 1994; Petralia et al., 1994a,b,c, 1996a, 1997a,b; Sato et al., 1995; for review, see Wenthold et al., 1993, 1997a,b). In the present study, we examined the endbulb synapses on spherical bushy cells of the dorsorostral AVCN to determine the kinds of AMPA receptors involved in endbulb neurotransmission. We used preembedding immunoperoxidase and postembedding immunogold in combination (Petralia et al., 1997a; Rubio and Wenthold, 1997) to show that the major glutamate receptors of the endbulb synapse are AMPA receptor complexes containing mainly GluR3 and GluR4, suggesting that most of these glutamate receptors are calcium permeable and exhibit a rapid response. The latter characteristics of AVCN endbulb synapses may be essential for sound localization.

\section{MATERIALS AND METHODS}

Antibody production, purification, and characterization. Details of antibody production, purification, and characterization have been described previously (Table 1 ). GluR2/3 antibody also is called GluR2/3/4c because it recognizes the variant GluR4c (Gallo et al., 1992). Monoclonal and polyclonal antibodies to GluR2/3 generally produced similar distribu- 
Table 1. Antibodies used to localize glutamate receptors

\begin{tabular}{|c|c|c|}
\hline \multirow[b]{2}{*}{ Receptors } & \multicolumn{2}{|l|}{ Concentration } \\
\hline & $\begin{array}{l}\text { Preembedding } \\
\text { immunoperoxidase }\end{array}$ & $\begin{array}{l}\text { Postembedding } \\
\text { immunogold }\end{array}$ \\
\hline GluR1 $^{a}$ & $2-2.5 \mu \mathrm{g} / \mathrm{ml}$ & \\
\hline $\mathrm{GluR}^{b}$ & $1-2 \mu \mathrm{g} / \mathrm{ml}$ & 1.3 or $4 \mu \mathrm{g} / \mathrm{ml}$ \\
\hline GluR2/3 ${ }^{a}$ (poly) & $1 \mu \mathrm{g} / \mathrm{ml}$ & $1.3 \mu \mathrm{g} / \mathrm{ml}$ \\
\hline GluR2/3 $3^{c, d}$ (mono) & & $0.7 \mu \mathrm{g} / \mathrm{ml}$ \\
\hline GluR4 $4^{a}$ & $1.2-1.4 \mu \mathrm{g} / \mathrm{ml}$ & $1.2 \mu \mathrm{g} / \mathrm{ml}$ \\
\hline
\end{tabular}

${ }^{a}$ Wenthold et al., 1992.

${ }^{b}$ Petralia et al., 1997a.

${ }^{c}$ Nusser et al., 1994.

${ }^{d}$ Ottiger et al., 1995.

tions in the brain (Petralia and Wenthold, 1992; Petralia et al., 1996b, 1997a; Rubio and Wenthold, 1997).

Preembedding immunoperoxidase: tissue preparation. Young male Sprague Dawley rats (125-250 gm) were anesthetized and perfused transcardially as described previously (Petralia and Wenthold, 1992; Petralia et al., 1994a,b,c, 1996a,b, 1997a,b). The fixative was cold 4\% paraformaldehyde in $0.12 \mathrm{M}$ phosphate buffer, $\mathrm{pH} 7.2-7.3$, with or without $0.1 \%$ glutaraldehyde; glutaraldehyde was added mainly for electron microscope studies. Brains were removed, fixed, and sectioned with a vibratome (Pelco DTK-3000W microslicer) at $50 \mu \mathrm{m}$. To minimize movements of the cochlear nuclei during sectioning, $1 \%$ agarose in PBS was sometimes used. Some vibratome sections were infiltrated with $30 \%$ sucrose in PBS, frozen using acetone cooled with dry ice, and stored at $-80^{\circ} \mathrm{C}$; these sections were thawed and rinsed in PBS.

All experiments at National Institutes of Health were performed in accordance with the National Institutes of Health Guide for the Care and Use of Laboratory Animals (National Institutes of Health Publication no. 85-23). All efforts were made to minimize animal suffering, to reduce the number of animals used, and to use alternatives to in vivo techniques. Animal protocols used in this study at National Institutes of Health were approved by the National Institute of Neurological Diseases and Stroke/ National Institute on Deafness and Other Communication Disorders Animal Care and Use Committee.

Preembedding immunoperoxidase: immunocytochemistry. Sections were incubated in $10 \%$ normal goat serum (NGS) in PBS (blocking solution for polyclonal antibodies) for $1 \mathrm{hr}$ and in primary antibody overnight at $4^{\circ} \mathrm{C}$, and further processed with avidin-biotin-peroxidase (Vectastain kit; Vector Laboratories, Burlingame, CA) and 3',3-diaminobenzidine tetrahydrochloride as described previously.

Sections used for electron microscopy were fixed in $1 \%$ osmium tetroxide, dehydrated, and embedded in Poly/BED 812 resin (Polysciences, Warrington, PA) as described previously (Petralia and Wenthold, 1992). Thin sections of $\sim 75 \mathrm{~nm}$ were cut from the edge of the $50 \mu \mathrm{m}$ vibratome sections (i.e., perpendicular to the plane of the section), using an LKB Ultratome IV or Leica Reichert Ultracut S ultramicrotome, and examined without further staining in a JEOL JEM-100CX II transmission electron microscope at $60 \mathrm{kV}$. Most thin sections were taken from parasagittal vibratome sections from the lateral part of the AVCN; thin sections usually were cut perpendicular to the base of the AVCN and were from the rostral portion of the section.

Postembedding immunogold. The technique used in the present study has been described (Petralia et al., 1997a; Rubio and Wenthold, 1997; Wang et al., 1997) and is a modification of a technique published previously (Matsubara et al., 1996; Landsend et al., 1997). Male Wistar rats prepared in Norway were anesthetized and perfused as described in the last two studies, and male Sprague Dawley rats prepared at National Institutes of Health were anesthetized and perfused as described above for preembedding immunoperoxidase. The fixative that was used was $4 \%$ paraformaldehyde plus $0.5 \%$ glutaraldehyde. Washing and vibratomy were performed in phosphate buffer $(0.1 \mathrm{M}$ with/without $4 \%$ glucose $)$. Tissue (300 $\mu \mathrm{m}$ sections or hand-cut pieces) was then cryoprotected using a series of 10, 20, and $30 \%$ glycerol (last step overnight) in $0.1 \mathrm{M}$ phosphate buffer and was plunge-frozen in liquid propane in a Leica KF80 (Norway) or EM CPC (National Institutes of Health). Frozen tissue was immersed in $1.5 \%$ uranyl acetate in methanol at $-90^{\circ} \mathrm{C}$ in a Leica AFS freeze-substitution instrument, infiltrated in Lowicryl HM 20 resin at $-45^{\circ} \mathrm{C}$, and polymerized with $\mathrm{UV}$ light $\left(-45^{\circ} \mathrm{C}\right.$ to $\left.0^{\circ} \mathrm{C}\right)$. Thin sections were cut on an ultramicrotome as described for preembedding immunoperoxidase.

In some cases, immunolabeling was preceded by etching in sodium ethanolate, but usually this was not done. Then sections were incubated in $0.1 \%$ sodium borohydride $+50 \mathrm{~mm}$ glycine in Tris-buffered saline/ $0.1 \%$ Triton X-100 (TBST) for $10 \mathrm{~min}$. Grids were incubated in blocking serum in TBST for 10 min $(10 \%$ NGS in most cases; $2 \%$ human serum albumin in some cases). Then grids were incubated in primary antibody in serum/TBST for $2 \mathrm{hr}$, followed by washes in TBST, blocking in serum/TBST, and incubation in 1:20 immunogold (Amersham, Arlington Heights, IL) in serum/TBST plus $0.5 \%$ polyethylene glycol $(20,000$ molecular weight); 5,10 , or $15 \mathrm{~nm}$ immunogold particles were used for single labeling and $5+15 \mathrm{~nm}$ used for double labeling. After further washes, sections were dried and stained with $1 \%$ uranyl acetate and $0.3 \%$ lead citrate.

$A V C N$ cytology. In the rat, large spherical bushy cells form the only major cell type of the rostral area of the AVCN and were designated as type c round cells (with large endbulbs) by Harrison and Irving (1965); these probably correspond to the large spherical cells of the cat (Osen, 1969; Webster, 1995). This area was designated as area III of the ventral cochlear nucleus by Harrison and Irving (1965). Just caudal to area III is area I, which contains spherical bushy cells known as type i round cells (with pale endbulbs) and type h large multipolar cells; the type i round cells probably correspond to the small spherical cells of the cat (Osen, 1969; Webster, 1995). The spherical cell axon projects via the trapezoid body to the ipsilateral lateral superior olive (LSO) and bilaterally to the medial superior olive (MSO) (Webster, 1995). The remainder of the AVCN (caudal and ventral areas) is part of area II and contains type $\mathrm{g}$ oval cells (with modified endbulbs) and some other cell types. Areas I and III together correspond to the anterior division or spherical cell area of the AVCN described in other animals (cat: Osen, 1969, Brawer et al., 1974, Cant and Morest, 1979a; chinchilla: Morest et al., 1990; guinea pig: Hackney et al., 1990; mouse: Webster and Trune, 1982; Bilak et al., 1996; rat: Webster, 1995). In addition to spherical bushy cells, the anterior division of the AVCN contains stellate cells, with the majority found in the more caudal (posterior) portion.

Areas surveyed. Ultrastructural studies were limited to the rostrodorsal region (i.e., spherical cell area) of the $\mathrm{AVCN}$, so that all identified endbulb synapses are likely to be associated with spherical bushy cells.

In this study, neuronal staining refers to staining of the cell body, excluding the nucleus, and of major dendrites that were traced from the cell body, whereas neuropilar staining refers to staining of processes not traced to specific cell bodies and the unresolvable matrix between cells (Petralia and Wenthold, 1992; Petralia et al., 1994a,b; our unpublished data).

Coronal sections of the AVCN typically included sections from two to three levels from rostral to caudal (based on Paxinos and Watson, 1986) and were taken from the following numbers of animals: GluR1, $n=6$; GluR2/3, $n=5$; GluR4, $n=3$; and PBS controls, $n=8$. Parasagittal sections of the AVCN typically included sections from three to four levels from lateral to medial and were taken from the following numbers of sides/numbers of animals: GluR1, $n=33 / 25$; GluR2, $n=10 / 10$; GluR2/3, $n=23 / 19$; GluR4, $n=30 / 18$; and PBS controls, $n=50 / 38$. For immunoperoxidase electron microscopy, thin sections were examined from parasagittal sections taken from the following numbers of animals: GluR1, $n=1$; GluR2, $n=4$; GluR2/3, $n=7$; GluR4, $n=5$; and PBS controls, $n=4$.

For postembedding immunogold, thin sections were examined from one block from each of two animals for each antibody: GluR2, GluR2/3, and GluR4. In addition, four cells (GluR2/3 antibody) were examined in a series of up to 21 consecutive sections (with some missing sections). Within this series, a subseries of 13 sections was used to reconstruct part of the synaptic contact region of one large endbulb, to elucidate the shapes and positions of 26 synapse-active zones, and to determine the distribution of gold particles in these active zones. Sections used in these series were collected on formvar/carbon-coated single-slot grids (Electron Microscopy Sciences, Fort Washington, PA) and thus could only be labeled on one side of the section. Immunogold counts at synapses included all gold particles found in the synaptic cleft and postsynaptic density (Rubio and Wenthold, 1997). Synapse measurements were taken on $50,000 \times$ prints.

Controls. Controls included (1) immunoblot analyses of brain regions and peripheral organs (Wenthold et al., 1990, 1992; Petralia et al., 1997a), (2) controls in which PBS was substituted for the primary antibody (PBS 


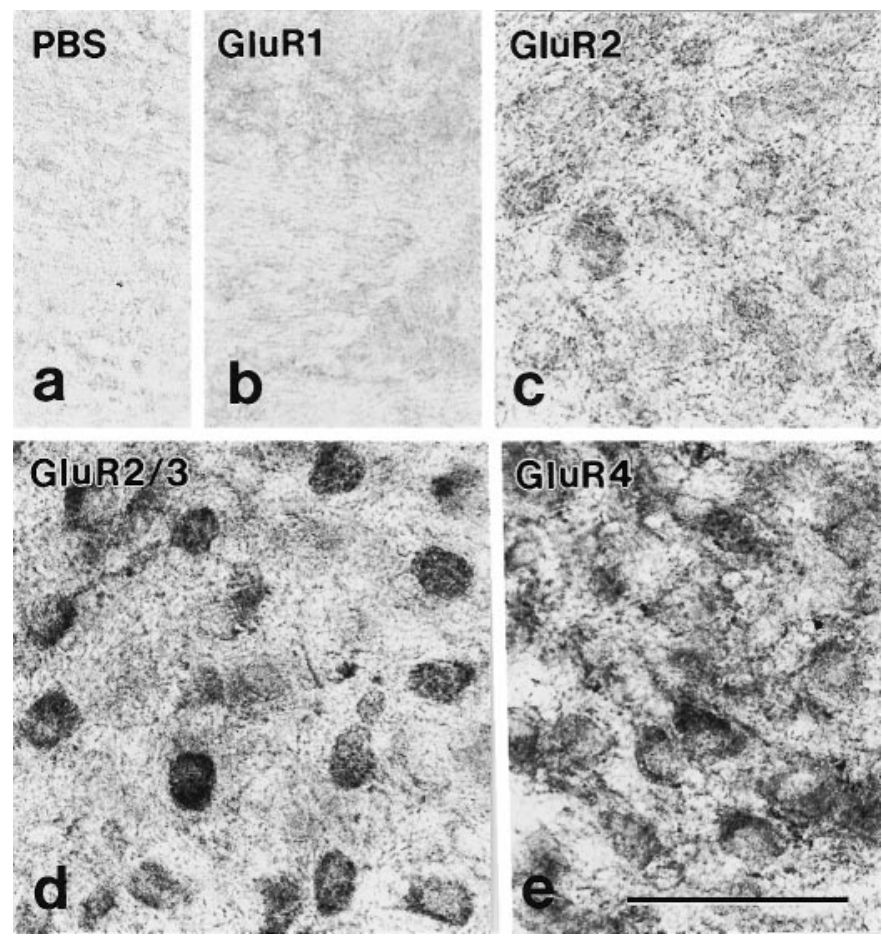

Figure 1. Parasagittal sections of the rostrodorsal portion of the anteroventral cochlear nucleus, immunolabeled with antibodies to GluR1 $(b)$, GluR2 (c), GluR2/3 (d), and GluR4 (e). a, PBS control. Note the absence of staining in the control, little or no staining for GluR1, light staining for GluR2, moderately dense staining for GluR2/3, and moderate to moderately dense staining for GluR4. Scale bar, $50 \mu \mathrm{m}$.

controls), and (3) preadsorption controls in which each antibody was incubated with its corresponding peptide (Petralia and Wenthold, 1992; Petralia et al., 1997a). PBS controls were performed on some sections in every run of all experiments.

For immunogold, there were 10 control experiments (designated here as Experiments 1-10): (1) NGS/TBST only substituted for the primary antibody, along with one each of five different gold-labeled secondary antibodies $-5 \mathrm{~nm}$ (control Experiment 1) and $10 \mathrm{~nm}$ (Experiment 2) goat anti-rabbit, and 5 (Experiment 3), 10 (Experiment 4), and 15 (Experiment 5) nm goat anti-mouse; (2) GluR4 primary antibody along with either $15 \mathrm{~nm}$ goat anti-mouse (Experiment 6), or $5 \mathrm{~nm}$ goat anti-rabbit $+15 \mathrm{~nm}$ goat anti-mouse (Experiment 7); and (3) GluR2/3 monoclonal primary antibody along with one each of three different secondary antibody combinations $-5 \mathrm{~nm}$ goat anti-rabbit only (Experiment 8$), 5 \mathrm{~nm}$ goat anti-rabbit $+15 \mathrm{~nm}$ goat anti-mouse (Experiment 9), and $5 \mathrm{~nm}$ goat anti-mouse $+15 \mathrm{~nm}$ goat anti-rabbit (Experiment 10).

This study combines two established methods (i.e., immunoperoxidase, immunogold) for immunocytochemical localization of glutamate receptors. Generally, similar results were obtained with the two methods, providing strong evidence that the described glutamate receptor distribution is real, as shown previously for other types of neurons (Petralia et al., 1997a; Rubio and Wenthold, 1997). Thus, this combined method can act as a control for method-based artifacts. For both techniques, concentrations of primary antibodies were selected to produce little or no background staining at light or electron microscope levels. Such background artifactual staining was examined in both control sections and within the experimental sections, in structures that are presumed not to contain glutamate receptors. Immunoperoxidase- and immunogoldlabeled sections were considered acceptable if they showed little or no labeling inside the mitochondria and nucleus.

\section{RESULTS}

\section{Light microscopy}

Sagittal (Fig. 1) and coronal sections of the AVCN gave similar results for immunostaining with antibodies to the AMPA receptor subunits. There was little or no staining with GluR1 antibody, light staining with GluR2 antibody, moderate to moderately dense staining with GluR4 antibody, and moderately dense staining with antibody to GluR2/3. Staining with the latter two antibodies was prevalent in all regions [I, II, and III of Harrison (Harrison and Irving, 1965)] and was found in presumptive spherical cells (identified by their location, medium to large size, and round to ovoid shape), as well as in various types of multipolar neurons throughout the AVCN. GluR2/3 and GluR4 antibodies also produced many densely staining puncta in the neuropil of the AVCN, and GluR4 antibody stained numerous fine neuropilar processes.

\section{Electron microscopy: identification of spherical cell synapses}

This study was limited mostly to identified spherical cell synapses. Identification of spherical cells was based largely on the identification of endbulb synapses on the cell body, because the other major neurons of this region, the stellate or medium-sized multipolar cells, do not bear endbulbs (for review, see Cant, 1992). Endbulb synapses contain large round vesicles in a very large terminal that makes multiple, asymmetric synaptic contacts (active zones) with a large soma. Often, these active zones extend slightly into the presynaptic terminal; sometimes the postsynaptic membrane is found on the side of a short spine projecting into the endbulb. Attachment plaques are seen between the endbulb and the soma. Attachment plaques (term refers specifically to the individual densities) or puncta adherentia (term refers to the entire junctional complex) are identified by the large, similar preand postsynaptic densities, straight cell membranes, and widened cleft (in some cases, a thin, intermediate dense line can be seen in the middle of the cleft); these junctions have not been well studied and may include more than one morphological variant (Gulley et al., 1978; Cant and Morest, 1979b). In comparison, only the postsynaptic density is thick in the endbulb active zones. The endbulbs also form synapses with dendrites (i.e., on the side of the endbulb opposite that of the somal/endbulb synapse); in addition, synapses are formed with the base of the main dendrite projecting from the soma.

Criteria for positive identification of a spherical bushy cell were based on the presence of endbulbs, but also on cell shape and size. Rat spherical bushy cells are large and roughly oval in shape (Saldaña et al., 1988). The nuclear "cap" of Nissl, which is well defined in cat spherical bushy cells (Osen, 1969; Cant, 1981), tends to be poorly developed in guinea pigs (Hackney et al., 1990) and chinchillas (Morest et al., 1990) and was never distinct in our rat sections. Cells used in this study had at least one endbulb profile contacting the cell; identification was based on published descriptions and micrographs (Lenn and Reese, 1966; Gentschev and Sotelo, 1973; Cant and Morest, 1979b; Cant, 1981; Rees et al., 1985; Ryugo and Sento, 1991; Ryugo et al., 1996). All large round vesicle-containing synapses, on a soma having an identified endbulb profile, were considered to be portions of endbulb synapses, based on previous auditory nerve degeneration studies (Cant and Morest, 1979b; Cant, 1981).

\section{Electron microscopy: immunoperoxidase}

Little or no staining was seen with antibody to GluR1 in spherical cells. Staining with antibody to GluR2 was low in spherical cells. Low to moderate staining was seen in some postsynaptic membranes and densities at round vesicle synapses, including endbulb profiles (Fig. 2). In contrast to GluR1 and GluR2 antibodies, antibodies to GluR2/3 and GluR4 produced substantial cytoplas- 


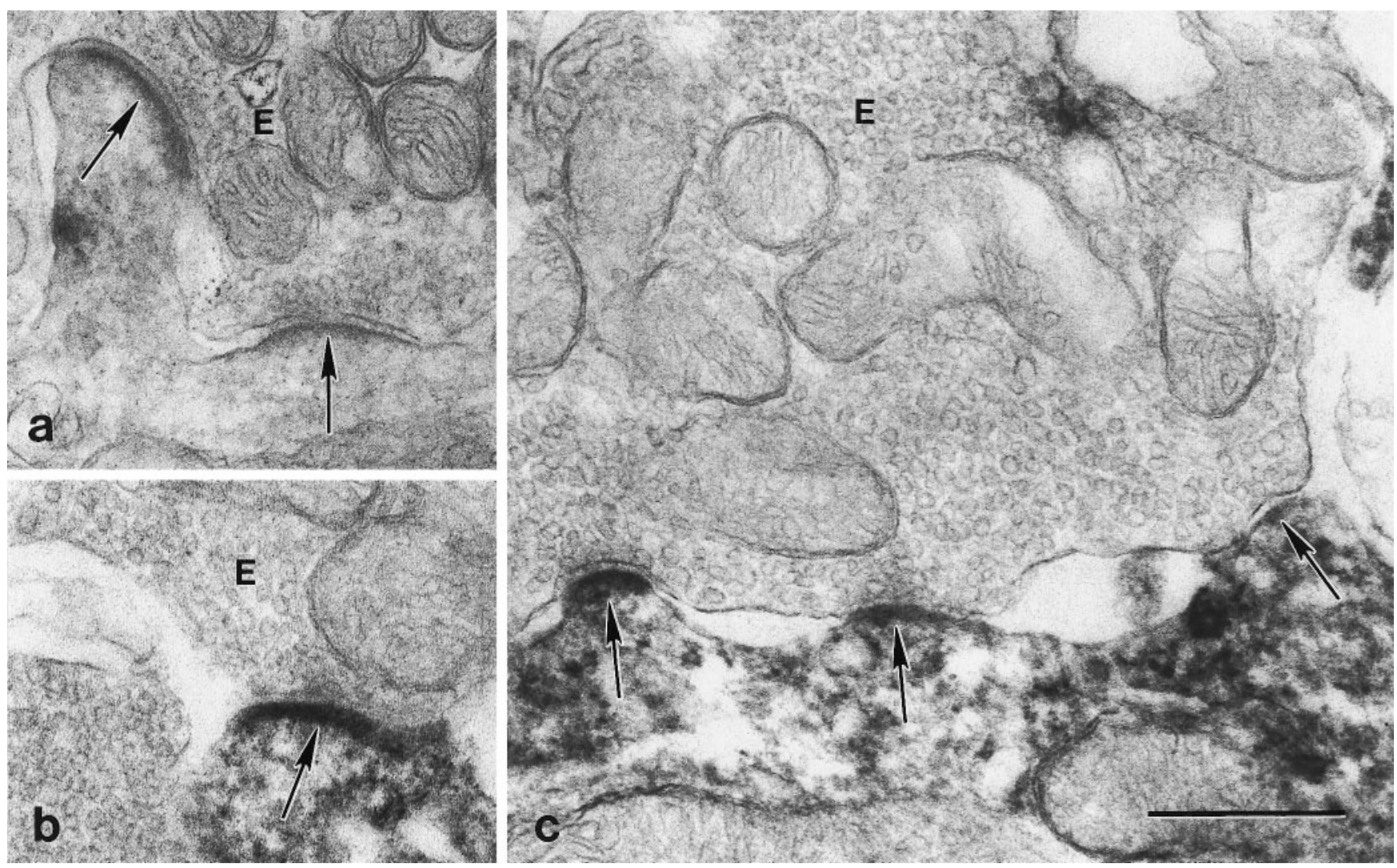

Figure 2. Electron micrographs of the anteroventral cochlear nucleus immunolabeled (immunoperoxidase method) with antibodies to GluR2 ( $a$ ), GluR2/3 (b), and GluR4 (c). E, Endbulb. Arrows indicate postsynaptic densities on spherical cells. Note the dense staining seen in synapses immunolabeled for GluR2/3 or GluR4. In contrast, low staining is seen in the synapses labeled for GluR2 (staining in the synapse on the right may not be above background). A distinct patch of staining is seen in the neck of the spine on the left in $a$; in contrast, patches of staining are common in the cytoplasm of cells labeled with GluR2/3 or GluR4 antibodies. Note also the patch of staining for GluR4 seen in the presynaptic terminal (compare with presynaptic gold-labeling in Fig. 5). The stained process in the top right corner of $c$ is probably a glial process. Scale bar, $0.5 \mu \mathrm{m}$.

mic staining in spherical cell bodies as well as in many dendrites throughout the adjacent neuropil. With antibody to GluR4, patches of staining often were particularly prevalent on Golgi complexes. Staining with antibodies to GluR2/3 and GluR4, in postsynaptic membranes and densities in active zones of round vesicle synapses including endbulbs, was common and ranged from light to dense (Fig. 2). However, unstained active zones were seen frequently at these synapses. Postsynaptic staining also was common in active zones of dendrites forming synapses with endbulbs (i.e., opposite the endbulb-spherical cell soma synapse).

\section{Electron microscopy: immunogold}

On the basis of the patterns of receptor distribution suggested by the immunoperoxidase studies, immunogold labeling was used to localize more accurately labeling for antibodies to GluR2, GluR2/3, and GluR4. Gold particles $(10 \mathrm{~nm})$ were associated with the active zones of round vesicle synapses, including endbulbs on spherical cell somas, using antibodies to GluR2/3 (Fig. 3) and GluR4 (Figs. 4, 5). Two or more gold particles were found at $86 \%$ (average, 4.28 gold particles per synapse, counting all gold particles and all endbulb synapses) (Table 2) of individual synapses in sections labeled with antibody to GluR2/3 and at $71 \%$ (average, 2.37 gold particles per synapse) of individual synapses in sections labeled with antibody to GluR4. In comparison, immunogold labeling was uncommon at these active zones using antibody to GluR2 (9\%; average, 0.40 gold particles per synapse). Immuno- gold labeling increased only slightly when the concentration of primary antibody was increased (from $1.33 \mu \mathrm{g} / \mathrm{ml}$ to $4 \mu \mathrm{g} / \mathrm{ml}$ ) and the gold size reduced (from $10 \mathrm{~nm}$ to $5 \mathrm{~nm}$ ) to maximize gold labeling (Table 2); the latter antibody concentration and gold size were identical to those used in a study of GluR2 immunolabeling in fusiform cell synapses of the dorsal cochlear nucleus, where substantial GluR2 labeling was found (Rubio and Wenthold, 1997). The gold particles seen at the endbulb synapses with the AMPA receptor antibodies usually were associated closely with the postsynaptic membrane. However, a few gold particles sometimes were found on the presynaptic side of these synapses with antibody to GluR4 (Fig. 5); presynaptic gold was seen only rarely with GluR2/3 or GluR2 (Fig. 3). Postsynaptic gold labeling also was common $(50-60 \%)$ at active zones of synapses of dendrites forming contacts with endbulbs (i.e., on the side opposite that of the somal-endbulb synapse (Figs. 3, 5; Table 2). Sometimes gold-labeled synapses were found on short spines projecting from the soma into the endbulb (Fig. 5); rarely, these spines extended to the opposite surface of the endbulb (Fig. 3). Thus, we cannot rule out that some of the smaller dendrite processes, counted in this study, actually are somal projections (Cant and Morest, $1979 b)$. Double labeling (15 $\mathrm{nm}+5 \mathrm{~nm}$ gold) showed that GluR2/3 (monoclonal antibody) (Rubio and Wenthold, 1997) and GluR4 immunolabeling colocalized frequently at round vesicle synapses on spherical cell somas (Fig. 6; Table 3).

Reconstruction of endbulb active zone areas using a series of 

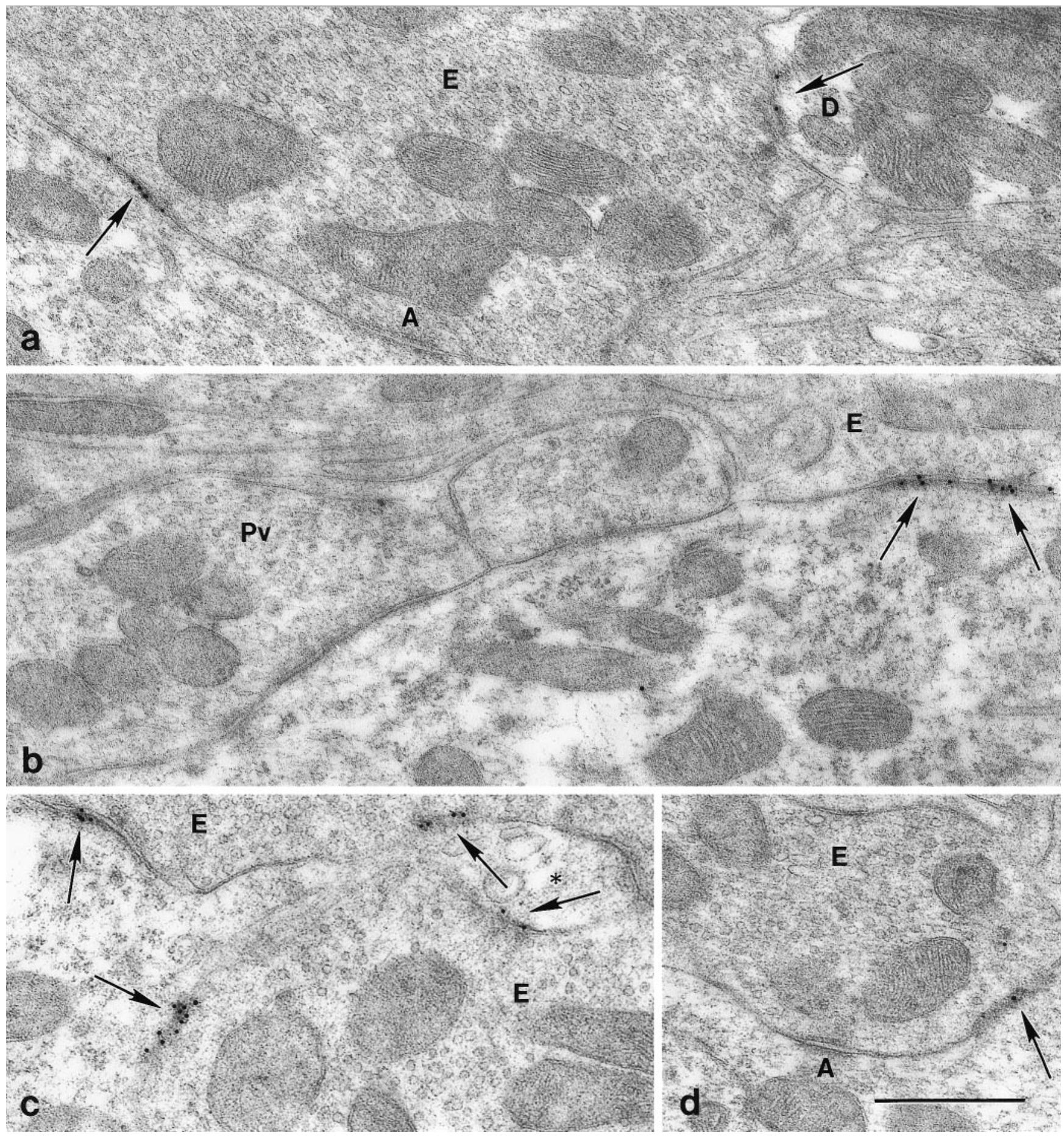

Figure 3. Electron micrographs of the anteroventral cochlear nucleus immunolabeled (immunogold method; $10 \mathrm{~nm}$ gold) with antibodies to GluR2/3 $(a-c)$ and GluR2 $(d)$. A, Attachment plaque; $D$, dendrite-forming synapse with endbulb; $E$, endbulb; $P v$, synapse with pleomorphic vesicles; asterisk, spine projecting from spherical cell body; arrows, postsynaptic membrane. The vesicles in the endbulb in $a$ have been artifactually flattened by compression. Note that the postsynaptic density of the endbulb synapse in $b$ is slightly attenuated in the center where gold is absent; this may be a perforated synapse. Scale bar, $0.5 \mu \mathrm{m}$.

consecutive sections immunolabeled with antibody to GluR2/3 showed that gold particles could be concentrated centrally in the synapse in many cases and peripherally in some cases (Fig. 7). It also showed that only a small population of synapses has no gold along the entire surface area of the active zone. This confirms that labeling for these AMPA receptor subunits is found in most synapse-active zones.
Tangential distribution of gold particles along the postsynaptic membrane for antibodies to GluR2, GluR2/3, and GluR4 was fairly even, with the majority of gold particles within the central three-quarters of the postsynaptic membrane (Fig. 8). These three histograms were based on the inclusion of all goldcontaining synaptic active zones used in the study from Table 2. Two additional sets of three histograms also were prepared (not 


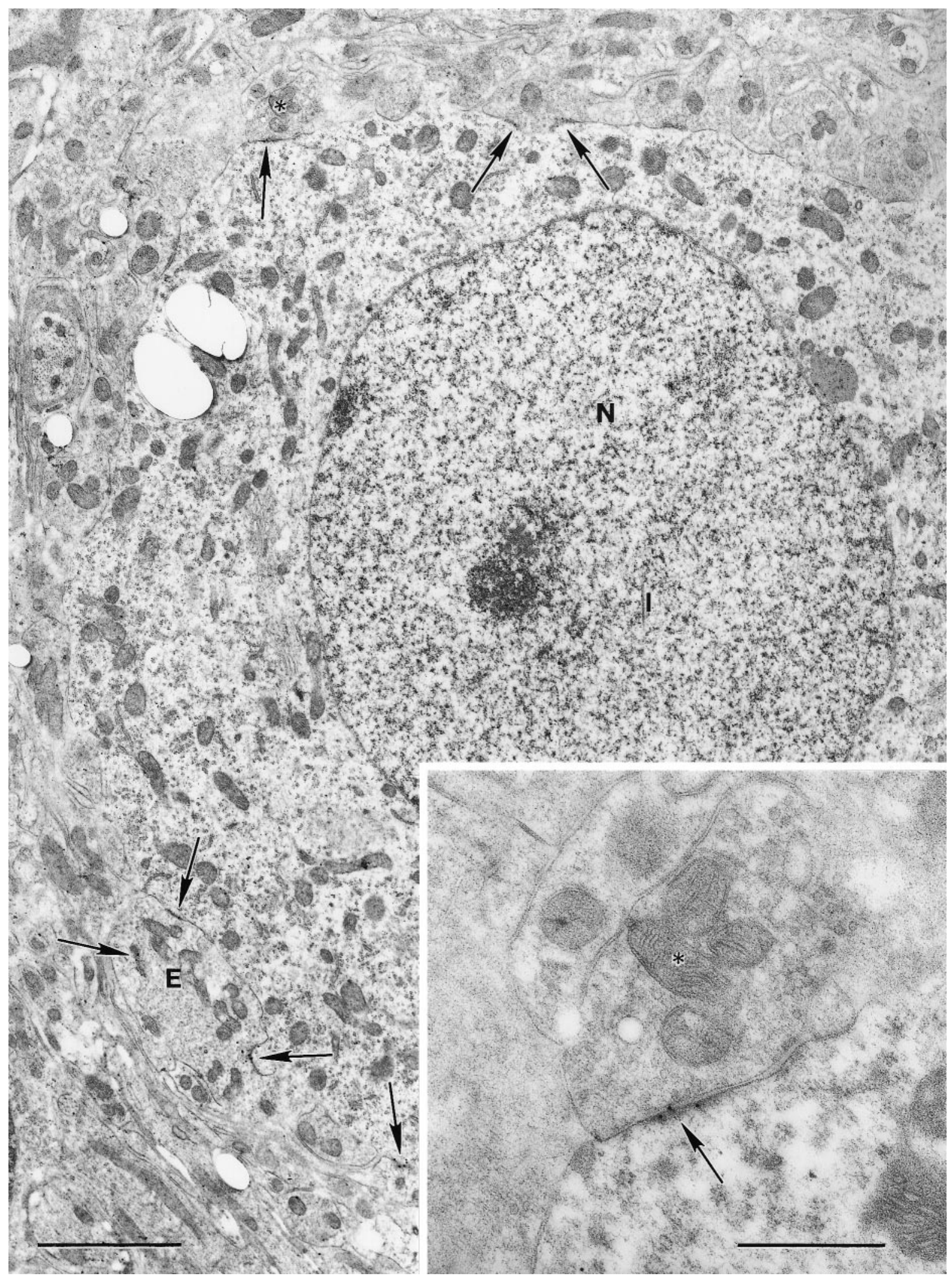

Figure 4. Electron micrograph of the anteroventral cochlear nucleus immunolabeled (immunogold method; 10 nm gold) with antibody to GluR4. About half of the cell profile is included in the micrograph. This micrograph illustrates the overall pattern of endbulb-synapse terminal profiles along the somal membrane. One of these terminals (asterisk) is shown at high magnification in the inset. $E$, Endbulb shown at higher magnification in Figure 5; $I$, Intranuclear rod (Feldman and Peters, 1972); $N$, nucleus; arrows, postsynaptic densities labeled with gold. Scale bar, $2 \mu \mathrm{m}$; inset scale bar, $0.5 \mu \mathrm{m}$. 


\begin{tabular}{|c|c|c|c|c|c|}
\hline $\begin{array}{l}\text { Receptors (gold } \\
\text { size) }\end{array}$ & $\begin{array}{l}\text { Number } \\
\text { of cells }\end{array}$ & $\begin{array}{l}\text { Number of gold } \\
\text { particles/PSDs }\end{array}$ & $\begin{array}{l}\text { Average length } \\
\text { of PSD }(\mu \mathrm{m})\end{array}$ & $\begin{array}{l}\text { Average number of gold } \\
\text { particles per PSD } \\
\text { (range) }\end{array}$ & $\begin{array}{l}\text { Number of gold particles } \\
\text { per } \mu \mathrm{m} \text { of PSD } \pm \text { SE }\end{array}$ \\
\hline \multicolumn{6}{|c|}{ Round vesicle synapses } \\
\hline GluR2/3 (10 nm) & 12 & $334 / 78$ & 0.27 & $4.28(0-15)$ & $15.6 \pm 1.2$ \\
\hline GluR4 (10 nm) & 5 & $83 / 35$ & 0.32 & $2.37(0-10)$ & $8.1 \pm 1.2$ \\
\hline GluR2 (10 nm) & 8 & $20 / 50$ & 0.27 & $0.40(0-2)$ & $1.5 \pm 0.4$ \\
\hline GluR2 (5 nm) & 12 & $37 / 85$ & 0.32 & $0.44(0-3)$ & $1.8 \pm 0.4$ \\
\hline \multicolumn{6}{|l|}{ Dendrite on endbulb } \\
\hline GluR2/3 (10 nm) & 12 & $21 / 13$ & 0.23 & $1.62(0-4)$ & $7.6 \pm 1.8$ \\
\hline GluR4 (10 nm) & 5 & $9 / 5$ & 0.32 & $1.80(0-4)$ & $4.9 \pm 2.1$ \\
\hline GluR2 (10 nm) & 7 & $0 / 5$ & 0.20 & 0 & 0 \\
\hline GluR2 (5 nm) & 17 & $1 / 7$ & 0.27 & $0.14(0-1)$ & $0.4 \pm 0.4$ \\
\hline
\end{tabular}

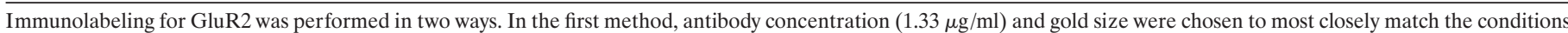

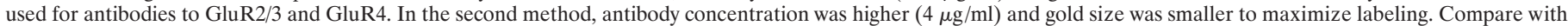
values reported for synapses on fusiform cells of the dorsal cochlear nucleus (Rubio and Wenthold, 1997, their Table 2). PSD, Postsynaptic density.

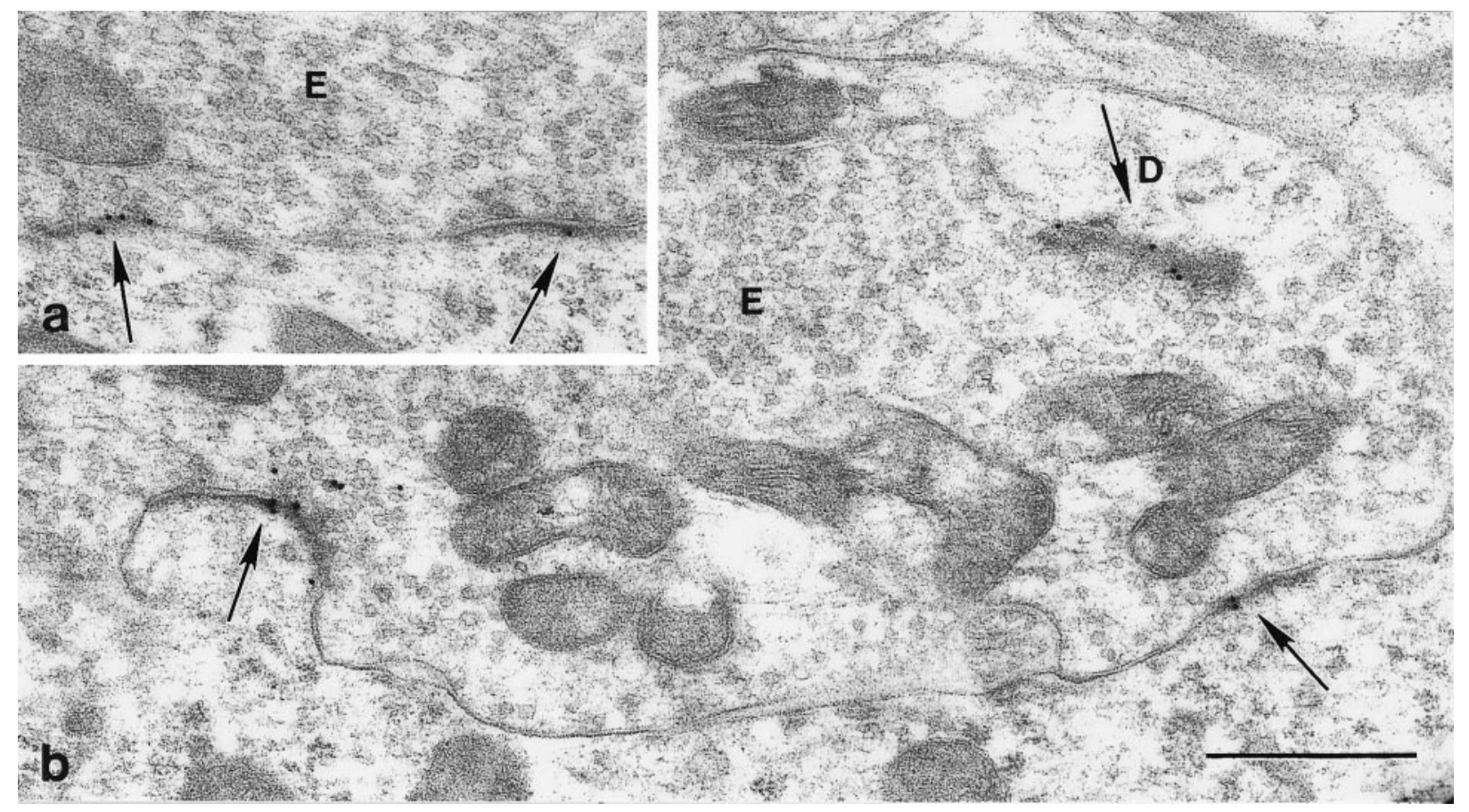

Figure 5. Electron micrographs of the anteroventral cochlear nucleus immunolabeled (immunogold method; $10 \mathrm{~nm}$ gold) with antibody to GluR4. The endbulb in $b$ is shown at lower magnification in Figure 4. Note that four gold particles are found in the presynaptic terminal away from the plasma membrane. $D$, Dendrite forming synapse with endbulb; $E$, endbulb; arrows, postsynaptic densities. Scale bar, $0.5 \mu \mathrm{m}$.

shown) using samples restricted to active zone profiles with a diameter of $>250$ and $300 \mathrm{~nm}$, to avoid the inclusion of peripheral cuts through active zones (Landsend et al., 1997). These limits were based on the smallest active zones seen in the serial reconstruction (Fig. $7 g$ ) at about $200 \mathrm{~nm}$; by comparison, serial reconstructions through cat endbulbs show some active zones $<200 \mathrm{~nm}$ (Ryugo et al., 1996) and within the range of the smallest active zone profiles used in our study. Distributions of gold particles seen in these histograms were similar overall to those seen in Figure 8 .

\section{Controls}

Controls for immunoperoxidase labeling were negative using both light (Fig. 1) and electron microscopy. Gold particles were rare or absent in controls for immunogold labeling.

\section{DISCUSSION}

To our knowledge, this study provides the first morphological evidence for glutamate receptors on the postsynaptic membrane of auditory nerve-endbulb synapses on spherical bushy cells of the AVCN. Both preembedding immunoperoxidase and postembedding immunogold techniques showed that the major type of postsynaptic glutamate receptor of endbulbs is an AMPA receptor containing mainly GluR3 and GluR4 subunits. This suggests that endbulb AMPA receptors are calcium-permeable and desensitize rapidly; such characteristics may facilitate auditory neurotransmission. The immunogold technique showed that endbulb AMPA receptors are present at most synapse-active zones throughout the endbulb-soma contact zone and are distributed evenly along the postsynaptic membrane. 

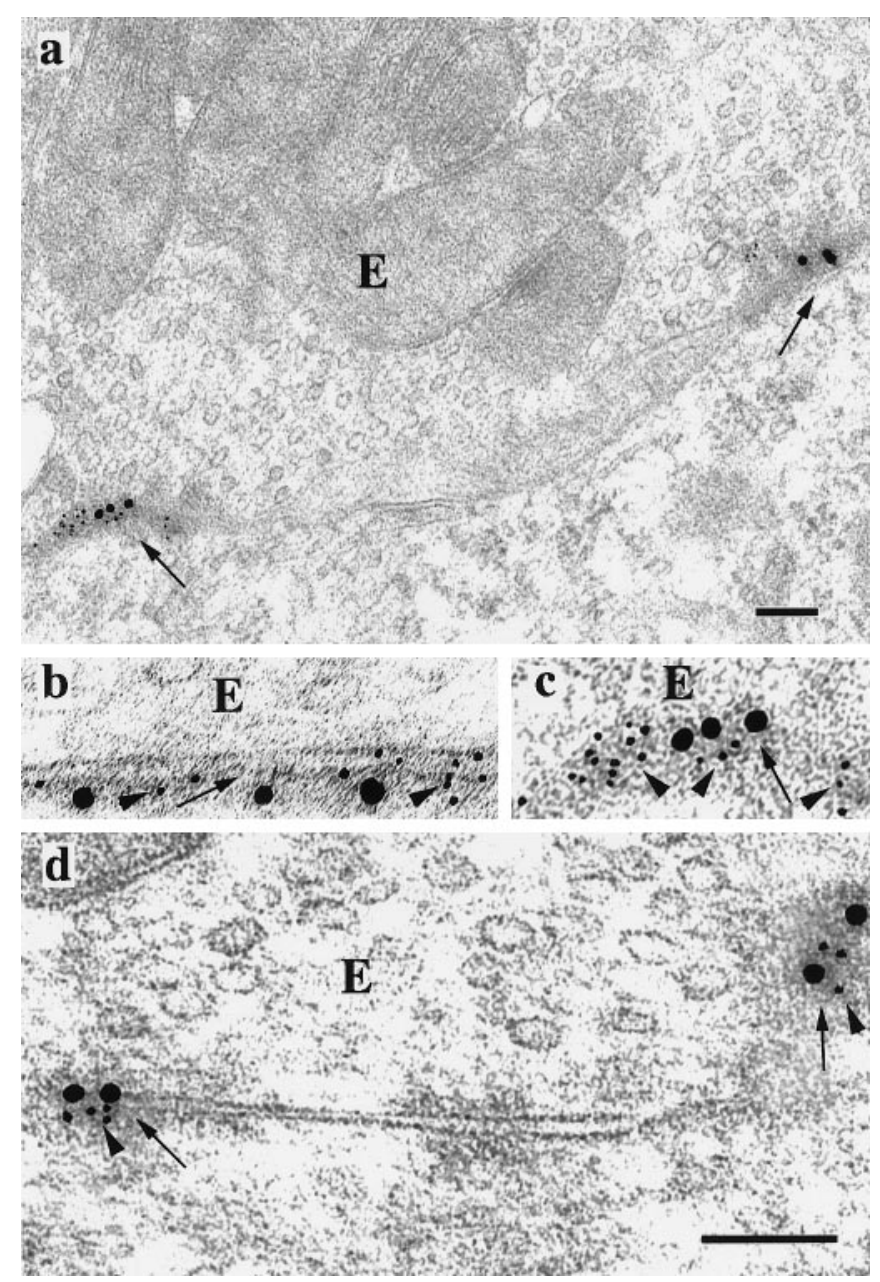

Figure 6. Electron micrographs of the anteroventral cochlear nucleus double-labeled (immunogold method) with antibodies to GluR2/3 (monoclonal; $15 \mathrm{~nm})$ and GluR4 $(5 \mathrm{~nm})$. Arrows, Gold-labeled postsynaptic densities; arrowheads, groups of $5 \mathrm{~nm}$ gold particles. The ovoid appearance of the vesicles in these examples is caused by the artifactual compression of the round vesicles of these endbulb $(E)$ synapses. The synapse in $c$ is oblique and is a high magnification of the left synapse in $a$. Scale bar, $0.1 \mu \mathrm{m}$ (same scale for $b-d$ ).

\section{Expression and organization of AMPA receptors at endbulb synapses}

AMPA receptors found postsynaptic to spherical cell-primary auditory terminals contain GluR3 and GluR4, but few may contain GluR2, and GluR1 may be absent or rare. Previous in situ hybridization studies indicate that spherical cells contain (1) GluR2, GluR3, and GluR4, but not GluR1 mRNA; (2) low levels of GluR2 mRNA and moderate levels of GluR3 mRNA (GluR4 mRNA expression was not quantified); and (3) only one-fourth to one-fifth as much GluR2 mRNA as is found in fusiform cells of the dorsal cochlear nucleus or cerebellar Purkinje cells (Hunter et al., 1993). Light microscope immunoperoxidase studies have shown similar results for receptor protein levels. Based on the present study, along with an earlier general study of the brain including the cochlear nuclei (Petralia et al., 1997a), there is little or no staining in the AVCN with GluR1 antibody, low staining with GluR2 antibody, and moderate to dense staining with GluR2/3 and GluR4 antibodies (similar findings have been de- scribed in avian cochlear nuclei although GluR2 antibody was not used) (Levin et al., 1997), again suggesting that the major AMPA receptor subunits of the AVCN are GluR3 and GluR4. By comparison, both GluR2 and GluR2/3 antibodies produced substantial staining in the dorsal cochlear nucleus (Petralia et al., 1996b, 1997a), suggesting that GluR2 is more common in neurons of the dorsal cochlear nucleus than in neurons of the AVCN. In the present study, GluR2 immunogold labeling at endbulb synapses is about one-fifth ( 0.44 gold particles per synapse) of that found at two kinds of fusiform cell synapses (dorsal cochlear nucleus: 1.9 gold particles per synapse for auditory nerve synapses; 2.2 gold particles per synapse for parallel fiber synapses) (Rubio and Wenthold, 1997), using identical antibody concentrations and gold particle sizes. (Because only low levels of GluR2 immunolabeling are found throughout the $\mathrm{AVCN}$, a direct comparison with synapses rich in GluR2 within the AVCN could not be made.) This ratio is remarkably similar to that obtained for mRNA, supporting the suggestion that GluR2 subunits are infrequent in spherical cells and spherical cell-endbulb synapses. Use of two concentrations of the GluR2 antibody provides further proof that a low GluR2/GluR3 ratio is a real phenomenon at endbulb synapses and that this antibody is labeling all available epitopes, i.e., the labeling intensity for GluR2 does not show a further increase after using higher antibody concentrations. Another alternative explanation for low immunolabeling with GluR2 antibody is that epitope accessibility is compromised because of interference by associated proteins. However, the only described AMPA receptor-associated protein, GRIP, appears to interact with the far C terminus of GluR2 (Dong et al., 1997), i.e., the site of epitopes for GluR2/3 antibody but not for GluR2 antibody (Petralia et al., 1997a).

The serial reconstruction of part of an endbulb showed a structure and a distribution of active zones similar to those described in the cat (Ryugo et al., 1996, 1997). AMPA receptors are found in most active zones of endbulbs and also are spread throughout each active zone-postsynaptic membrane. The overall even distribution of AMPA receptor subunits in the active zones was demonstrated using both serial reconstructions and linear tangential measurements along the individual section profiles and is consistent with findings in other studies of ionotropic glutamate receptors in the CNS (AMPA, Nusser et al., 1994; Baude et al., 1993, 1995; Bernard et al., 1997; delta, Landsend et al., 1997). Finally, the perpendicular distribution of immunogold particles in the synapse indicates a postsynaptic localization of AMPA receptors at the endbulb synapse, consistent with findings in other areas of the nervous system (Nusser et al., 1994; Baude et al., 1995; Bernard et al., 1997). Occasional presynaptic gold particles seen with GluR4 antibody is consistent with findings in other regions (Baude et al., 1995; Matsubara et al., 1996); however, this evidence for presynaptic GluR4 is preliminary and requires more detailed analysis in a future study.

\section{AMPA receptor function at endbulb synapses}

These data indicate that many endbulb-AMPA receptors may be composed of GluR3 + GluR4 and lack GluR2. Such AMPA receptors are calcium-permeable and show rapid desensitization (Jonas et al., 1994; Mosbacher et al., 1994; Geiger et al., 1995; Jonas and Burnashev, 1995). Calcium-permeable AMPA receptors are found in a number of cell types in the nervous system, and there is a close negative correlation between abundance of GluR2 and calcium-permeability in neurons (Geiger et al., 1995; Jonas and Burnashev, 1995; Seeburg, 1996; Petralia, 1997). Jonas 
Table 3. Colocalization of postembedding immunoreactivity for glutamate receptor subunits GluR2/3 and GluR4 at synapses on spherical bushy cells

\begin{tabular}{|c|c|c|c|c|}
\hline Receptors (gold size) & $\begin{array}{l}\text { Number of gold } \\
\text { particles/PSDs }\end{array}$ & $\begin{array}{l}\text { Average } \\
\text { length of } \\
\text { PSD }(\mu \mathrm{m})\end{array}$ & $\begin{array}{l}\text { Average number of gold } \\
\text { particles per PSD } \\
\text { (range) }\end{array}$ & $\begin{array}{l}\text { Number of gold particles } \\
\text { per } \mu \mathrm{m} \text { of PSD } \pm \mathrm{SE}\end{array}$ \\
\hline \multicolumn{5}{|l|}{ Round Vesicle Synapses } \\
\hline GluR2/3 (15 nm) & $170 / 92$ & 0.26 & $1.8(0-6)$ & $7.2 \pm 0.5$ \\
\hline GluR4 (5 nm) & $286 / 92$ & & $3.1(0-13)$ & $12.6 \pm 1.2$ \\
\hline \multicolumn{5}{|l|}{ Dendrite on endbulb } \\
\hline GluR2/3 (15 nm) & $34 / 20$ & 0.24 & $1.7(0-8)$ & $6.5 \pm 1.9$ \\
\hline GluR4 (5 nm) & $36 / 20$ & & $1.8(0-5)$ & $7.2 \pm 1.4$ \\
\hline \multicolumn{5}{|c|}{ Number of synapses labeled with either or both antibodies } \\
\hline & GluR2/3 \& GluR4 & GluR2/3 only & GluR4 only & No gold \\
\hline Round vesicle synapse & $62(67 \%)$ & $8(9 \%)$ & $9(10 \%)$ & $13(14 \%)$ \\
\hline Dendrite on endbulb & $8(40 \%)$ & $3(15 \%)$ & $6(30 \%)$ & $3(15 \%)$ \\
\hline
\end{tabular}

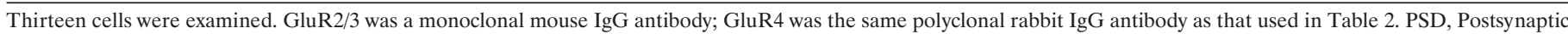
density.

et al. (1994), using patch clamping and single-cell PCR, found that nonpyramidal neocortical neurons have high calcium permeability and low GluR2 expression (a complete absence of GluR2 was rare), whereas pyramidal neurons have relatively low calcium permeability and high GluR2 expression. Geiger et al. (1995), using similar techniques, examined neurons from several brain regions and concluded that the calcium permeability of native AMPA receptors is inversely correlated with relative abundance of GluR2. In addition, for most types of neurons, their data are consistent with a model of a pentameric AMPA receptor in which a single GluR2 subunit is sufficient to produce heteromeric AMPA receptor complexes with low calcium permeability. Thus, neurons with only low levels of GluR2 (less than $\sim 25 \%$, based on relative abundance of GluR2 compared with the total of all AMPA receptor subunits) produce mostly GluR2-lacking, calcium-permeable AMPA receptors, and produce few GluR2containing, calcium-impermeable AMPA receptors (Jonas et al., 1994; Geiger et al., 1995; Jonas and Burnashev, 1995). Calciumpermeable AMPA receptors, presumably lacking GluR2, have been demonstrated in the avian cochlear nucleus (Otis et al., 1995; Zhou et al., 1995; Solum et al., 1997). AMPA receptors containing high levels of flop variants of GluR3 or GluR4 show rapid desensitization (Mosbacher et al., 1994). This allows rapid neurotransmission, as suggested for parts of the auditory system (Raman et al., 1994; Geiger et al., 1995). Rapid neurotransmission also may involve calcium entry through GluR2-lacking AMPA receptors; this could activate calcium-dependent potassium channels to facilitate termination of the excitatory postsynaptic potential (Geiger et al., 1995). A rapid response of spherical bushy cells to auditory nerve stimulation is expected, because these neurons are believed to act as relays of high-frequency information from the auditory nerve to other auditory centers (Isaacson and Walmsley, 1995). Rapid neurotransmission in the cochlear nucleus and other auditory nuclei may be necessary for accurate transmission of temporal signals involved in sound localization (Raman et al., 1994).

The high density of neurotransmitter release sites (i.e., active zones) and associated AMPA receptors at endbulb synapses may improve transmission of timing information (avian studies) (Trussell et al., 1993, Otis et al., 1996). Briefly, neurotransmitter release from multiple sites on endbulbs causes delayed clearance of neurotransmitter; this activates a steady potassium conductance that reduces the membrane time constant, thereby speeding and improving the precision of repetitive firing. This phenomenon also promotes desensitization, which may protect the cell from excessive calcium entry through these GluR2-lacking AMPA receptors.

\section{Other receptors at endbulb synapses}

Preliminary studies indicate that other types of glutamate receptors (kainate, delta, NMDA, metabotropic) exist only at low levels at endbulb synapses (one exception may be mGluR $1 \alpha$ at synapses between dendrites and endbulbs) (Wang et al., 1996, 1997; our unpublished data). This suggests that either these receptors play only minimal roles at endbulb synapses (for NMDA receptors, see Wickesberg and Oertel, 1989; Isaacson and Walmsley, 1995), or uncommon receptors are sufficient for significant function (for metabotropic receptors, see Lachica et al., 1995).

\section{Dendrite synapses}

Differences in immunolabeling with AMPA receptors were seen between endbulb-bushy cell soma synapses and endbulb-dendrite synapses. In the AVCN anterior division, the latter dendrites are almost certainly derived from spherical bushy cells; most likely they are distal dendrites from cells other than the one forming the somal synapses with that particular endbulb (Cant and Morest, 1979a,b; Rees et al., 1985; Ryugo and Sento, 1991; Ryugo et al., 1996). Immunogold particles for GluR2/3 and GluR4 immunolabeling were less frequent in endbulb-dendrite synapses compared with endbulb-soma synapses. If these differences occur in the same population of spherical bushy cells, postsynaptic AMPA receptors would be differentially distributed in these cells. Differential distribution of glutamate receptors has been reported for other neurons (Petralia et al., 1994a; Landsend et al., 1997; Rubio and Wenthold, 1997; Zhao et al., 1997). This is consistent with the reduced cytoplasmic content of the distal dendrites of spherical bushy cells and the paucity of their synaptic contacts, and it supports suggestions that these dendrites play only 

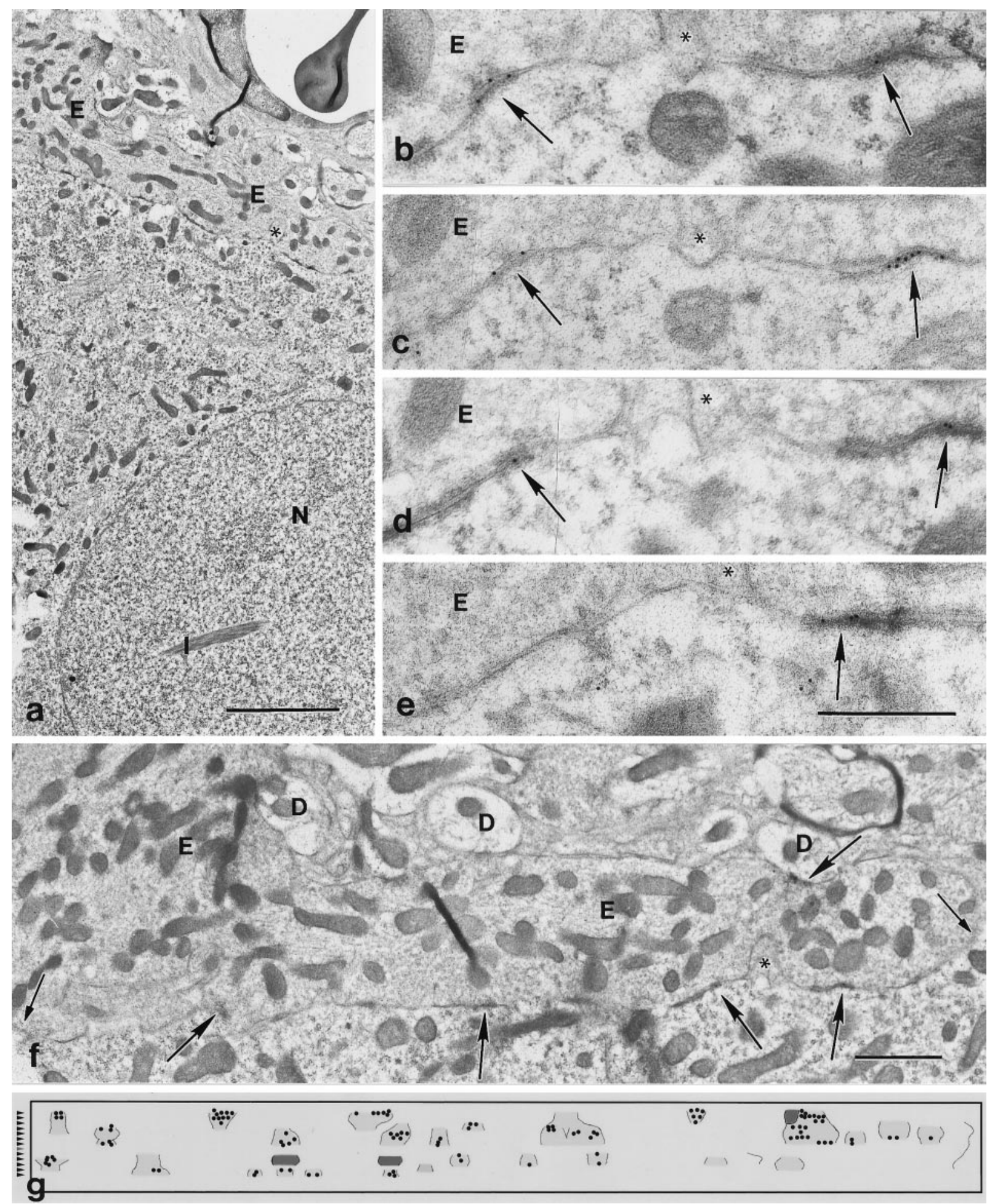

Figure 7. Electron micrographs of the anteroventral cochlear nucleus immunolabeled (immunogold method; $10 \mathrm{~nm}$ gold) with antibody to GluR2/3. Sections were taken in series through an endbulb on a spherical bushy cell $(a)$, and the positions of active zones and gold particles $(b-f)$ were mapped in two dimensions $(g) . a$, Seventh section in series shown at low magnification; this micrograph is included to illustrate the overall structure of the endbulb in relation to the spherical cell soma. $b-e$, Four sections from part of the endbulb synapse (sections 1-4 from the series). Asterisk demarcates the same position in all micrographs. $f$, Third section in the series, printed about the same size as the diagram in $g$. Small arrows denote the beginning and end of the endbulb region mapped in $g$. $g$, Diagram of the map of 13 serial sections of the endbulb. The beginning of each section is marked by an arrowhead on the far left; the eighth section was lost and is marked with a lighter arrowhead. Sections varied in thickness from silver to yellow, with an estimated average thickness of $70 \mathrm{~nm}$. This is represented on the diagram, with a total of $910 \mathrm{~nm}$ for the 13 sections. The synaptic active zones (all are in the same endbulb) are outlined and lightly shaded. Three attachment plaques are shaded more densely. Two separations in the plasma membrane of the endbulb are indicated by thin lines near the right. Gold particles are indicated by dots. The junctional complex seen in the far left of $b-d$ (including a single gold particle in $c$ ) is unclear and is not included in $g$. $D$, Dendrite forming synapse with endbulb (i.e., on the side opposite that of the somal/endbulb synapse); $E$, endbulb; $I$, intranuclear rod; $N$, nucleus; large arrows, postsynaptic densities with gold. Scale bars: $a, 3 \mu \mathrm{m} ; b-e, 0.5 \mu \mathrm{m} ; f, 1 \mu \mathrm{m}$. 

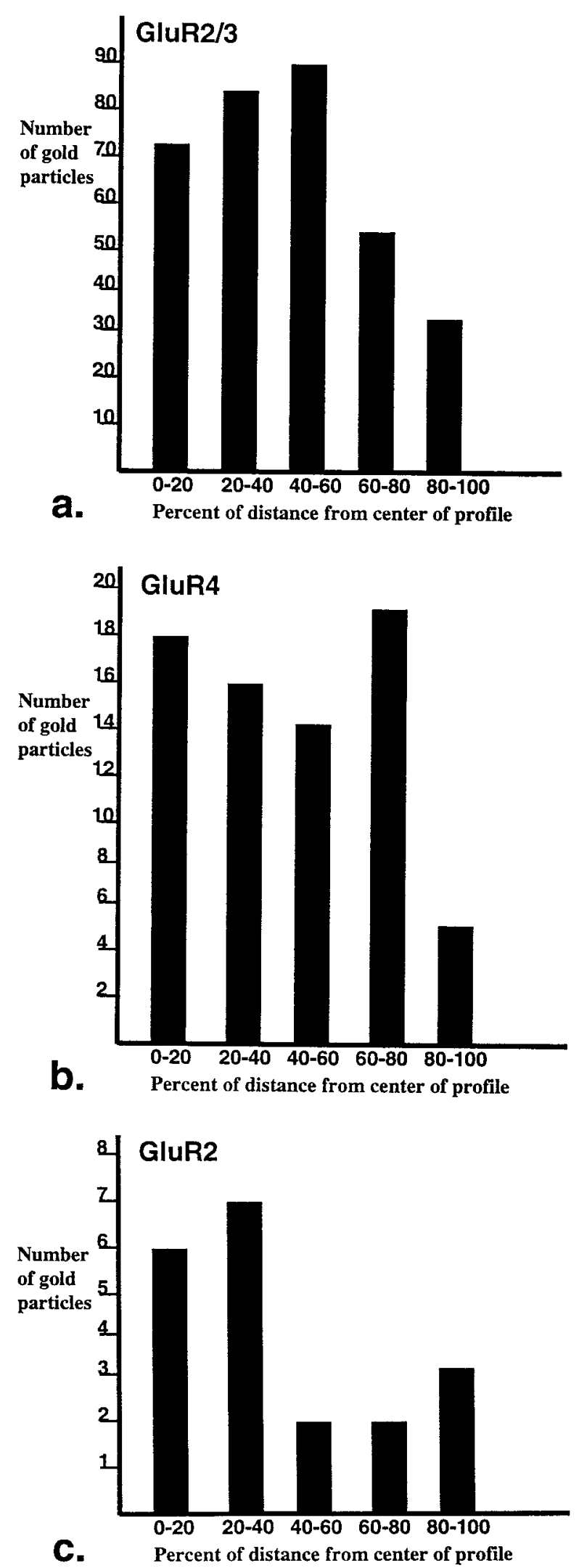

Figure 8. Tangential distribution of immunogold labeling $(10 \mathrm{~nm})$ with antibodies to GluR2/3 (a), GluR4 (b), and GluR2 (c) along endbulb active zone profiles, from 70,26 , and 16 synapses, respectively. a minor role in primary auditory neurotransmission (Cant and Morest, 1979b).

\section{REFERENCES}

Baude A, Nusser Z, Roberts JDB, Mulvihill E, McIlhinney RAJ, Somogyi $\mathrm{P}$ (1993) The metabotropic glutamate receptor (mGluR1 $\alpha$ ) is concentrated at perisynaptic membrane of neuronal subpopulations as detected by immunogold reaction. Neuron 11:771-787.

Baude A, Nusser Z, Molnár E, McIlhinney RAJ, Somogyi P (1995) High-resolution immunogold localization of AMPA type glutamate receptor subunits at synaptic and non-synaptic sites in rat hippocampus. Neuroscience 69:1031-1055.

Bernard V, Somogyi P, Bolam JP (1997) Cellular, subcellular, and subsynaptic distribution of AMPA-type glutamate receptor subunits in the neostriatum of the rat. J Neurosci [Correction (1997) 17:7180] $17: 819-833$

Bilak MM, Bilak SR, Morest DK (1996) Differential expression of $N$-methyl-D-aspartate receptor in the cochlear nucleus of the mouse. Neuroscience 75:1075-1097.

Brawer JB, Morest DK, Kane EC (1974) The neuronal architecture of the cochlear nucleus of the cat. J Comp Neurol 155:251-300.

Cant NB (1981) The fine structure of two types of stellate cells in the anterior division of the anteroventral cochlear nucleus of the cat. Neuroscience 6:2643-2655.

Cant NB (1992) The cochlear nucleus: neuronal types and their synaptic organization. In: The mammalian auditory pathway: Neuroanatomy (Fay RR, Popper AN, eds), pp 66-116. New York: Springer.

Cant NB, Morest DK (1979a) Organization of the neurons in the anterior division of the anteroventral cochlear nucleus of the cat. Lightmicroscopic observations. Neuroscience 4:1909-1923.

Cant NB, Morest DK (1979b) The bushy cells in the anteroventral cochlear nucleus of the cat. A study with the electron microscope. Neuroscience 4:1925-1945.

Dong H, O'Brien RJ, Fung ET, Lanahan AA, Worley PF, Huganir RL (1997) GRIP: a synaptic PDZ domain-containing protein that interacts with AMPA receptors. Nature 386:279-284.

Feldman ML, Peters A (1972) Intranuclear rods and sheets in rat cochlear nucleus. J Neurocytol 1:109-127.

Gallo V, Upson JM, Hayes W P, Vyklicky LJ, Winters CA, Buonanno A (1992) Molecular cloning and developmental analysis of a new glutamate receptor subunit isoform in cerebellum. J Neurosci 12:1010-1023.

Geiger JRP, Melcher T, Koh D-S, Sakmann B, Seeburg PH, Jonas P, Monyer H (1995) Relative abundance of subunit mRNAs determines gating and $\mathrm{Ca}^{2+}$ permeability of AMPA receptors in principal neurons and interneurons in rat CNS. Neuron 15:193-204.

Gentschev T, Sotelo C (1973) Degenerative patterns in the ventral cochlear nucleus of the rat after primary deafferentation. An ultrastructural study. Brain Res 62:37-60.

Gulley RL, Landis DMD, Reese TS (1978) Internal organization of membranes at end bulbs of Held in the anteroventral cochlear nucleus. J Comp Neurol 180:707-742.

Hackney CM, Osen KK, Kolston J (1990) Anatomy of the cochlear nuclear complex of guinea pig. Anat Embryol 182:123-149.

Hackney CM, Osen KK, Ottersen OP, Storm-Mathisen J, Manjaly G (1996) Immunocytochemical evidence that glutamate is a neurotransmitter in the cochlear nerve: a quantitative study in the guinea-pig anteroventral cochlear nucleus. Eur J Neurosci 8:79-91.

Harrison JM, Irving R (1965) The anterior ventral cochlear nucleus. J Comp Neurol 124:15-42.

Hunter C, Wenthold RJ (1994) Overlapping expression patterns for kainate-, NMDA- and AMPA-selective glutamate receptor subunit mRNAs in the rat cochlear nucleus. Assoc Res Otolaryngol Abstr 17:14.

Hunter C, Petralia RS, Vu T, Wenthold RJ (1993) Expression of AMPA-selective glutamate receptor subunits in morphologically defined neurons of the mammalian cochlear nucleus. J Neurosci 13:1932-1946.

Isaacson JS, Walmsley B (1995) Receptors underlying excitatory synaptic transmission in slices of the rat anteroventral cochlear nucleus. J Neurophysiol 73:964-973.

Jonas P, Burnashev N (1995) Molecular mechanisms controlling calcium entry through AMPA-type glutamate receptor channels. Neuron 15:987-990. 
Jonas P, Racca C, Sakmann B, Seeburg PH, Monyer H (1994) Differences in $\mathrm{Ca}^{2+}$ permeability of AMPA-type glutamate receptor channels in neocortical neurons caused by differential GluR-B subunit expression. Neuron 12:1281-1289.

Juiz JM, Helfert RH, Bonneau JM, Campos ML, Altschuler RA (1996a) Distribution of glycine and GABA immunoreactivities in the cochlear nucleus: quantitative patterns of putative inhibitory inputs on three cell types. J Hirnforsch 37:561-574.

Juiz JM, Helfert RH, Bonneau JM, Wenthold RJ, Altschuler RA (1996b) Three classes of inhibitory amino acid terminals in the cochlear nucleus of the guinea pig. J Comp Neurol 373:11-26.

Lachica EA, Rübsamen R, Zirpel L, Rubel EW (1995) Glutamatergic inhibition of voltage-operated calcium channels in the avian cochlear nucleus. J Neurosci 15:1724-1734.

Landsend AS, Amiry-Moghaddam M, Matsubara A, Bergersen L, Usami S, Wenthold RJ, Ottersen OP (1997) Differential localization of $\delta$ glutamate receptors in the rat cerebellum: coexpression with AMPA receptors in parallel fiber-spine synapses and absence from climbing fiber-spine synapses. J Neurosci 17:834-842.

Lenn NJ, Reese TS (1966) The fine structure of nerve endings in the nucleus of the trapezoid body and the ventral cochlear nucleus. Am J Anat 118:375-389.

Levin MD, Kubke MF, Schneider M, Wenthold, R, Carr CE (1997) Localization of AMPA-selective glutamate receptors in the auditory brainstem of the barn owl. J Comp Neurol 378:239-253.

Matsubara A, Laake JH, Davanger S, Usami S, Ottersen OP (1996) Organization of AMPA receptor subunits at a glutamate synapse: a quantitative immunogold analysis of hair cell synapses in the rat organ of Corti. J Neurosci 16:4457-4467.

Morest DK, Hutson KA, Kwok S (1990) Cytoarchitectonic atlas of the cochlear nucleus of the chinchilla, Chinchilla laniger. J Comp Neurol 300:230-248.

Mosbacher J, Schoepfer R, Monyer H, Burnashev N, Seeburg PH, Ruppersberg JP (1994) A molecular determinant for submillisecond desensitization in glutamate receptors. Science 266:1059-1062.

Nusser Z, Mulvihill E, Streit P, Somogyi P (1994) Subsynaptic segregation of metabotropic and ionotropic glutamate receptors as revealed by immunogold localization. Neuroscience 61:421-427.

Osen KK (1969) Cytoarchitecture of the cochlear nuclei in the cat. J Comp Neurol 136:453-484.

Otis TS, Raman IM, Trussell LO (1995) AMPA receptors with high $\mathrm{Ca}^{2+}$ permeability mediate synaptic transmission in the avian auditory pathway. J Physiol (Lond) 482:309-315.

Otis T, Zhang S, Trussell LO (1996) Direct measurement of AMPA receptor desensitization induced by glutamatergic synaptic transmission. J Neurosci 16:7496-7504.

Ottiger H-P, Gerfin-Moser A, Principe FD, Dutly F, Streit P (1995) Molecular cloning and differential expression patterns of avian glutamate receptor mRNAs. J Neurochem 64:2413-2426.

Paxinos G, Watson C (1986) The rat brain in stereotaxic coordinates, 2d ed. New York: Academic.

Petralia RS (1997) Immunocytochemical localization of ionotropic glutamate receptors (GluRs) in neural circuits. In: The ionotropic glutamate receptors (Monaghan DT, Wenthold RJ, eds), pp 219-263. Totowa, NJ: Humana.

Petralia RS, Wenthold RJ (1992) Light and electron immunocytochemical localization of AMPA-selective glutamate receptors in the rat brain. J Comp Neurol 318:329-354.

Petralia RS, Yokotani N, Wenthold RJ (1994a) Light and electron microscope distribution of the NMDA receptor subunit NMDAR1 in the rat nervous system using a selective anti-peptide antibody. J Neurosci 14:667-696.

Petralia RS, Wang Y-X, Wenthold RJ (1994b) The NMDA receptor subunits NR2A and NR2B show histological and ultrastructural localization patterns similar to those of NR1. J Neurosci 14:6102-6120.

Petralia RS, Wang Y-X, Wenthold RJ (1994c) Histological and ultrastructural localization of the kainate receptor subunits, KA2 and GluR6/7, in the rat nervous system using selective antipeptide antibodies. J Comp Neurol 349:85-110.

Petralia RS, Wang Y-X, Niedzielski AS, Wenthold RJ (1996a) The metabotropic glutamate receptors, mGluR2 and mGluR3, show unique postsynaptic, presynaptic and glial localizations. Neuroscience 71:949-976.
Petralia RS, Wang Y-X, Zhao H-M, Wenthold RJ (1996b) Ionotropic and metabotropic glutamate receptors show unique postsynaptic, presynaptic, and glial localizations in the dorsal cochlear nucleus. J Comp Neurol 372:356-383.

Petralia RS, Wang Y-X, Mayat E, Wenthold RJ (1997a) Glutamate receptor subunit 2-selective antibody shows a differential distribution of calcium-impermeable AMPA receptors among populations of neurons. J Comp Neurol 385:456-476.

Petralia RS, Wang Y-X, Singh S, Wu C, Shi L, Wei J, Wenthold RJ (1997b) A monoclonal antibody shows discrete cellular and subcellular localizations of mGluR $1 \alpha$ metabotropic glutamate receptors. J Chem Neuroanat 13:77-93.

Raman IM, Zhang S, Trussell LO (1994) Pathway-specific variants of AMPA receptors and their contribution to neuronal signaling. J Neurosci 14:4998-5010.

Rees S, Güldner FH, Aitkin L (1985) Activity dependent plasticity of postsynaptic density structure in the ventral cochlear nucleus of the rat. Brain Res 325:370-374.

Rhode WS, Greenberg S (1992) The mammalian auditory pathway: neurophysiology. In: Physiology of the cochlear nuclei (Arthur NP, Richard RF, eds), pp 94-152. New York: Springer.

Rubio ME, Wenthold RJ (1997) Glutamate receptors are selectively targeted to postsynaptic sites in neurons. Neuron 18:939-950.

Ryugo DK, Sento S (1991) Synaptic connections of the auditory nerve in cats: relationship between endbulbs of Held and spherical bushy cells. J Comp Neurol 305:35-48.

Ryugo DK, Wu MM, Pongstaporn T (1996) Activity-related features of synapse morphology: a study of endbulbs of Held. J Comp Neurol 365:141-158.

Ryugo DK, Pongstaporn T, Huchton DM, Niparko JK (1997) Ultrastructural analysis of primary endings in deaf white cats: morphologic alterations in endbulbs of Held. J Comp Neurol 385:230-244.

Saldaña E, Carro J, Merchan M, Collia F (1988) Morphometric and cytoarchitectural study of the different neuronal types in the VCN of the rat. In: Auditory pathway-structure and function satellite symposium (Syka J, Masterson RB, eds), pp 89-93. New York: Plenum.

Sato K, Kuriyama H, Altschuler RA (1995) Differential distribution of NMDA R2 subunits in the rat cochlear nucleus and superior olivary complex. Soc Neurosci Abstr 21:403.

Seeburg PH (1996) The role of RNA editing in controlling glutamate receptor channel properties. J Neurochem 66:1-5.

Solum D, Hughes D, Major MS, Parks TN (1997) Prevention of normally occurring and deafferentation-induced neuronal death in chick brainstem auditory neurons by periodic blockade of AMPA/kainate receptors. J Neurosci 17:4744-4751.

Trussell LO, Zhang S, Raman IM (1993) Desensitization of AMPA receptors upon multiquantal neurotransmitter release. Neuron 10:1185-1196.

Wang Y-X, Wenthold RJ, Petralia RS (1996) Distribution of glutamate receptor subunits associated with auditory nerve terminals in the anteroventral cochlear nucleus. Assoc Res Otolaryngol Abstr 19:168.

Wang Y-X, Wenthold RJ, Ottersen OP, Osen K, Petralia RS (1997) Localization of glutamate receptor subunits at endbulb synapses on spherical cells in the anteroventral cochlear nucleus. Assoc Res Otolaryngol Abstr 20:83.

Webster W R (1995) Auditory system. In: The rat nervous system, 2nd ed (G. Paxinos, ed), pp 797-831. New York: Academic.

Webster DB, Trune DR (1982) Cochlear nuclear complex of mice. Am J Anat 163:103-130.

Wenthold RJ, Hunter C (1990) Immunocytochemistry of glycine and glycine receptors in the central auditory system. In: Glycine neurotransmission (Ottersen OP, Storm-Mathisen J, eds), pp 391-416. New York: Wiley.

Wenthold RJ, Hunter C, Wada K, Dechesne CJ (1990) Antibodies to a C-terminal peptide of the rat brain glutamate receptor subunit, GluR-A, recognize a subpopulation of AMPA binding sites but not kainate sites. FEBS Lett 276:147-150.

Wenthold RJ, Yokotani N, Doi K, Wada K (1992) Immunochemical characterization of the non-NMDA glutamate receptor subunit-specific antibodies: evidence for a hetero-oligomeric structure in rat brain. J Biol Chem 267:501-507.

Wenthold RJ, Hunter C, Petralia RS (1993) Excitatory amino acid receptors in the rat cochlear nucleus. In: The mammalian cochlear nuclei: organization and function (Merchan MA, Juiz JM, Godfrey DA, Mugnaini E, eds), pp 179-194. New York: Plenum. 
Wenthold RJ, Hunter C, Petralia RS, Niedzielski AS, Wang Y-X, Safieddine S, Zhao H-M, Rubio ME (1997a) Receptors in the auditory pathway. In: Neurotransmission and hearing loss: basic science, diagnosis, and management (Berlin CI, ed), pp 1-23. San Diego: Singular.

Wenthold RJ, Wang Y-X, Petralia RS, Rubio ME (1997b) Distribution and targeting of glutamate receptors in the cochlear nucleus. In: Acoustical signal processing in the central auditory system (Syka J, ed), pp 93-107. New York: Plenum.

Wickesberg RE, Oertel D (1989) Auditory nerve neurotransmitter acts on a kainate receptor: evidence from intracellular recordings in brain slices from mice. Brain Res 486:39-48.
Wickesberg RE, Whitlon D, Oertel D (1994) In vitro modulation of somatic glycine-like immunoreactivity in presumed glycinergic neurons. J Comp Neurol 339:311-327.

Yao W, Godfrey DA, Levey AI (1996) Immunolocalization of muscarinic acetylcholine subtype 2 receptors in rat cochlear nucleus. J Comp Neurol 373:27-40.

Zhao H-M, Wenthold RJ, Wang Y-X, Petralia RS (1997) Delta glutamate receptors are differentially distributed at parallel and climbing fiber synapses on Purkinje cells. J Neurochem 68:1041-1052.

Zhou N, Taylor DA, Parks TN (1995) Cobalt-permeable non-NMDA receptors in developing chick brainstem auditory nuclei. NeuroReport 6:2273-2276. 